\title{
Review
}

\section{Molecular events associated with reactive oxygen species and cell cycle progression in mammalian cells}

\author{
Johannes Boonstra*, Jan Andries Post \\ Department of Cell Biology, Institute of Biomembranes, Utrecht University, Padualaan 8, 3584 CH Utrecht, The Netherlands
}

Received 6 February 2003; received in revised form 4 April 2004; accepted 26 April 2004

Received by A.J. van Wijnen

\begin{abstract}
Cell cycle progression is regulated by a wide variety of external factors, amongst them are growth factors and extracellular matrix factors. During the last decades evidence has been obtained that reactive oxygen species (ROS) may also play an important role in cell cycle progression. ROS may be generated by external and internal factors. In this overview we describe briefly the generation of ROS and their effects on processes that have been demonstrated to play an essential role in cell cycle progression, including such systems as signal transduction cascades, protein ubiquitination and degradation, and the cytoskeleton. These different effects of ROS influence cell cycle progression dependent upon the amount and duration of ROS exposure. Activation of growth factor stimulated signaling cascades by low levels of ROS result in increased cell cycle progression, or, in case of prolonged exposure, to a differentiation like growth arrest. From many studies it seems clear that the cyclin kinase inhibitor protein p21 plays a prominent role, leading to cell cycle arrest at higher but not directly lethal levels of ROS. Dependent upon the nature of p21 induction, the cell cycle arrest may be transient, coupled to repair processes, or permanent. At high concentrations of ROS all of the above processes are activated, in combination with enhanced damage to the building blocks of the cell, leading to apoptosis or even necrosis.
\end{abstract}

(C) 2004 Elsevier B.V. All rights reserved.

Keywords: Signal transduction; Cell cycle checkpoints; Apoptosis; Growth arrest; ROS

\section{Introduction}

Cells are able to duplicate by a process known as the cell cycle. This is one of the most fundamental properties of living organisms, allowing the organisms to reproduce themselves. Cell cycle research has gained enormous attention during the last decades, mainly because this knowledge is of considerable importance in fighting cancer as well as many other diseases. Knowledge on the regulation of cell

Abbreviations: AOX, antioxidants; E1, ubiquitin-activating enzyme; E2, ubiquitin-conjugating enzyme; GSH, glutathione; GPx, glutathione peroxidase; GR, glutathion reductase; $\mathrm{H}_{2} \mathrm{O}_{2}$, hydrogen peroxide; $\mathrm{LOOH}$, lipid-hydroperoxide; $\mathrm{LOO}^{\bullet}$, peroxylradical; $\mathrm{NADPH}$, nicotinamide adenine dinucleotide phosphate; $\mathrm{NO}^{\bullet}$, nitric oxide; $\mathrm{OH}^{\bullet}$, hydroxyl radical; $\mathrm{O}_{2}^{-}$, superoxide; $\mathrm{PLA}_{2}$, phospholipase $\mathrm{A}_{2}$; PUFA, polyunsaturated fatty acids; PTP, protein Tyr phosphatases; $\mathbf{R}^{\bullet}$, radical; ROS, reactive oxygen species; RTK, receptor tyrosine kinases; SOD, superoxide dismutase; Toc, tocopherol.

* Corresponding author. Tel.: +31-30-253-3189; fax: +31-30-251-3655

E-mail address: J.Boonstra@bio.uu.nl (J. Boonstra). cycle progression is also important for understanding embryonal development and is essential in many applied sciences. In general, cell cycle progression is regulated by external factors, amongst them are nutrients and growth factors. These external factors exhibit their effects on the cells by an elaborate intracellular signal transduction network, which ultimately results in progression through the cell cycle or alternatively to cell cycle arrest, cell differentiation or apoptosis. The features of the external cell cycle regulators as well as the signal transduction networks they activate have been subject of a wide variety of review articles, in which many details are described (see for instance: Heldin, 1996; Gutkind, 1998; Hulleman and Boonstra, 2001; Hulleman and van Rossum, 2003).

During the last decades it has become clear that in addition to the traditional cell cycle regulators as nutrients, growth factors and hormones, also less traditional factors may have an important impact on cell cycle regulation. Of these latter the reactive oxygen species (ROS) are of special interest. ROS are commonly thought to be toxic, resulting 
in oxidation of various cell constituents as DNA, lipids and proteins and consequently these oxidations may cause damage to the cellular machinery leading to cell death as the ultimate consequence. ROS have been implicated in an ever-increasing number of diseases and syndromes. These include various forms of non-hormone dependent cancers, atherosclerosis, ischemic reperfusion injury, neurodegenerative diseases, chronic inflammatory diseases, such as rheumatoid and psoriatic arthritis, and some factors underlying the ageing process itself (Halliwell and Gutteridge, 1999; Ames et al., 1993b; Shackelford et al., 2000). Whether ROS are the primary agents causing the disease, or formed secondary as a consequence of some metabolic disorder or environmental influence remains debatable and to some extent a matter of perspective. Next to playing a role in pathological conditions, evidence is now accumulating that ROS might also play a role as signaling molecules and as such they may have a role in cell cycle progression. In this contribution we will consider the effects of ROS in cells and describe the effects of ROS on cell cycle progression.

\section{Reactive oxygen species}

Free radicals are molecules that contain one or more unpaired electrons in their highest occupied atomic or molecular orbital. Because electrons are more stable when paired in orbitals, radicals are extremely reactive compared with non-radicals. Based on this definition a compound such as hydrogen peroxide can not be considered as a free radical. However since, in the presence of transition metals, $\mathrm{H}_{2} \mathrm{O}_{2}$ can easily give rise to the highly reactive hydroxyl radical $\left(\mathrm{OH}^{*}\right)$, in general one speaks of reactive oxygen species (ROS) rather than only oxygen free radicals.

ROS cannot only be formed by exogenous sources, but also by cells themselves, both actively and as a by-product of relevant biological processes (Table 1). For instance, phagocytic cells such as neutrophils and macrophages have

Table 1

Sources of reactive oxygen species (ROS)

Cellular

Mitochondrial respiratory chain

(NADPH)-oxidase complexes

Phagocytotic cells (ROS as part of defence system)

Other cells (ROS as 2nd messenger)

$\beta$-oxidation in peroxisomes

Prostaglandin synthesis (lipoxygenases and cycloxygenases)

Cytochrome P450 (detoxification reactions)

Non-cellular

Pollutants

Tobacco smoke

Iron salts

U.V. radiation

Ionizing radiation a unique superoxide $\left(\mathrm{O}_{2}^{-}\right)$producing system resulting in a respiratory burst that is activated in acute or chronic inflammation. The system producing $\mathrm{O}_{2}^{--}$is a nicotinamide adenine dinucleotide phosphate (NADPH)-oxidase complex (Fig. 1) and the ROS produced play a crucial role in the killing of microbes and neoplastic cells (Mackaness, 1970; Adams et al., 1982). Other intracellular sources of ROS are peroxisomes, the organelles responsible for oxidative metabolism of long chain fatty acids, producing $\mathrm{H}_{2} \mathrm{O}_{2}$ as a byproduct (Adams et al., 1982) and enzymes converting arachidonic acid, such as lipoxygenases. Another important source of endogenous production of ROS is the mitochondrial respiratory chain. Despite the fact that the mitochondrial electron transport chain is highly efficient, the nature of the alternating one-electron redox reactions catalysed by the mitochondrial complexes predispose each complex to side reactions with molecular oxygen. A small percentage (1$2 \%$ ) of the electrons passing through the mitochondrial electron transport chain leak out and combine with molecular oxygen to form ROS (Halliwell and Gutteridge, 1990, 1999; Davies, 1995). Partial reduction of molecular oxygen gives rise to species such as superoxide $\left(\mathrm{O}_{2}^{-}\right)$, hydrogen peroxide $\left(\mathrm{H}_{2} \mathrm{O}_{2}\right)$ and the hydroxyl radical $\left(\mathrm{HO}^{\circ}\right)$, all of which have been implicated in oxygen toxicity. Thus, ROS production in general occurs primarily as a ubiquitous byproduct of both oxidative phosphorylation and a myriad of oxidases necessary to support aerobic metabolism. Exogenous ROS sources are pollutants, tobacco smoke, which leads to a potent mixture of primarily nitrogen oxides $\left(\mathrm{NO}^{\bullet}\right)$ and hydroxyl radicals (HO•) (Stone and Pryor, 1994; Cosgrove et al., 1985), iron salts (Lauffer, 1992), diets containing plant food with large amounts of natural phenolic compounds (Gold et al., 1992), ultraviolet radiation (Cerutti, 1985), and ionizing radiation (Pollycove and Feinendegen, 2003) (Table 1).

Whatever their origin, ROS are formed in substantial amounts in living cells and these highly reactive species can damage a variety of biomolecules, such as lipids, proteins, carbohydrates and nucleic acids. As a consequence the majority of the effects of ROS on cells are a-specific, depending on the localization, nature and concentration of the ROS involved. The polyunsaturated fatty acids (PUFA) in lipids are opportune targets for free radicals. When free radicals react with lipid-PUFA, chain reactions generate radicals in profusion, which results in alteration of membrane permeability, modification of lipid-protein interactions, and the formation of bioactive degradation products (Halliwell and Gutteridge, 1990, 1999; Davies, 1995; RiceEvans and Burdon, 1993; Leonarduzzi et al., 2000). Proteins can be oxidatively modified, resulting in increases in the level of protein carbonyls (Levine, 2002), oxidized methionines (Stadtman and Levine, 2003) and/or cysteines (Stadtman, 2001; Davies, 2000), protein hydrophobicity (Meucci et al., 1991), cross-linked proteins (Squier, 2001) and glycated proteins (Baynes, 2001). These modifications might result in catalytically less active enzymes that are 


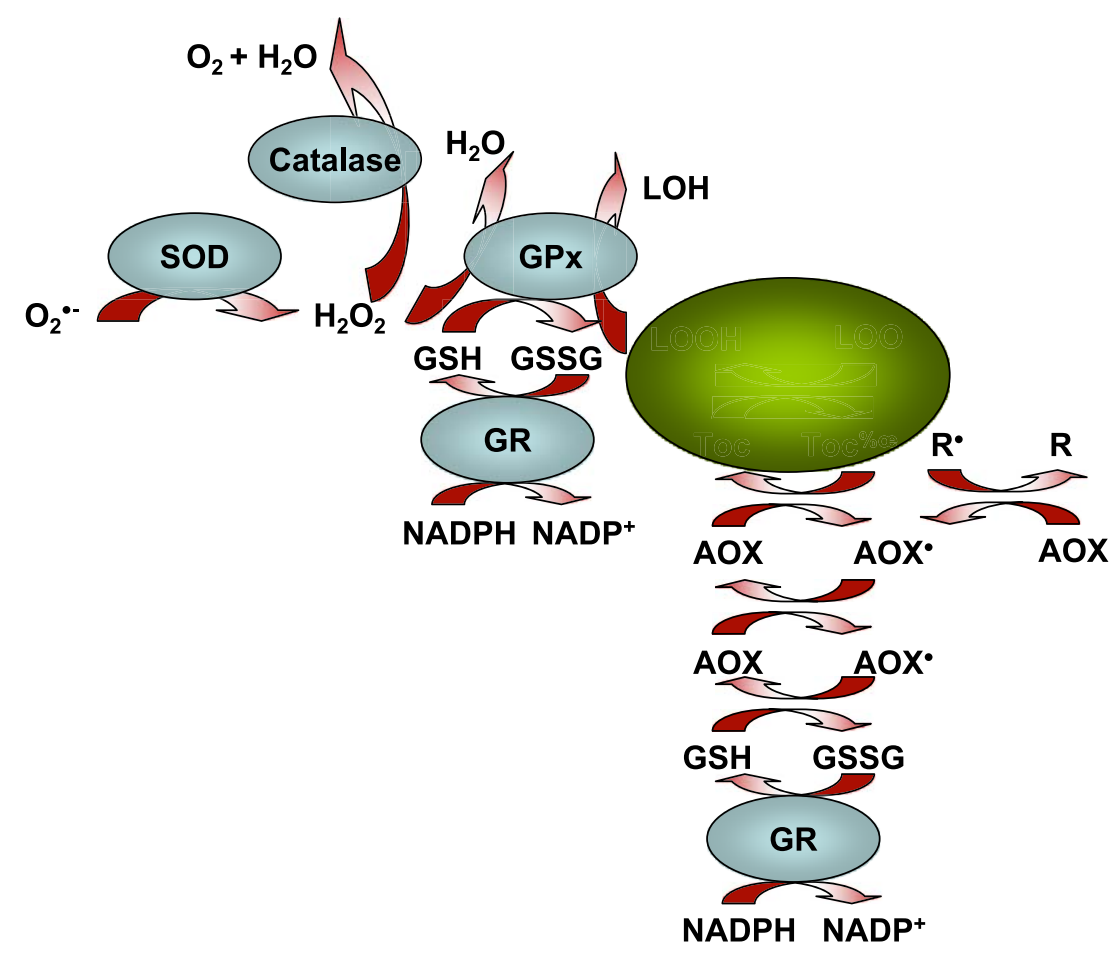

Fig. 1. Schematic representation of the major players of the cellular anti-oxidant network. The superoxide anion $\left(\mathrm{O}_{2}^{\bullet}\right)$ is dismutated by superoxide dismutase (SOD), present in mitochondria and the cytosol. The produced $\mathrm{H}_{2} \mathrm{O}_{2}$, which could give rise to the formation of the extremely noxious hydroxylradical, can be neutralized by catalase (in the peroxysomes) and by the cytosolic and mitochondrial glutathione peroxidase (GPx). The latter enzyme removes $\mathrm{H}_{2} \mathrm{O}_{2}$ by oxidizing glutathione (GSH) to GSSG, which is subsequently reduced to its original from by Glutathion Reductase (GR), at the expense of NADPH. A second form of GPx can reduce more complex hydroperoxides, such as lipid-hydroperoxides (LOOH). Low molecular weight antioxidants or scavengers, such as tocopherol, ascorbate and glutathione, can neutralize radicals (for instance the peroxylradical (LOO ${ }^{\bullet}$ ) and other radicals $\left(\mathrm{R}^{\bullet}\right)$ ) and are often subsequently regenerated by one or more other antioxidants (AOX and GSH). Tocopherol (Toc) is an AOX that resides in cellular membranes (green circle), whereas other AOXs, such as ascorbate and GSH, are located in the cytosol. For an extensive review of the cellular antioxidant network one is referred to Halliwell and Gutteridge, 1999.

more susceptible to proteolytic degradation, although the oxidation of methionines and cysteines is reversible (Stadtman, 2001; Davies, 2000; Stadtman and Levine, 2003). Of the different cell organelles specifically the Enodoplasmic Reticulum resident proteins seem to be most prone to oxidative damage (Van der Vlies et al., 2003). DNA is also a target of ROS and oxidative damage to DNA might result in mutagenesis (Ames et al., 1993a,b; Wilson et al., 2003; Cooke et al., 2003). Clearly, if cells were unprotected against ROS major damage to all cellular components would frequently occur.

At the cellular level an extensive defense system against ROS has been evolved, antioxidants are the first line of defense against ROS. They comprise of enzymes, such as superoxide dismutase, catalase and glutathione peroxidases, which complete the reduction of ROS to water (Fig. 1). Next to this, small molecules, as vitamins $\mathrm{E}$ and $\mathrm{C}$, complement the antioxidant enzymes and they are either synthesized by cells and tissues or absorbed from diet. They are capable of neutralising ROS and can be regenerated by the cellular anti-oxidant network, in which both enzymatic and nonenzymatic antioxidants take part (Halliwell and Gutteridge, 1999).
When the first line of defense fails various enzymes repair oxidatively damaged molecules. Oxidised lipid bilayers become better substrates for phospholipase enzymes. Phospholipase $\mathrm{A}_{2}\left(\mathrm{PLA}_{2}\right)$ has been shown to preferentially hydrolyse fatty acids from oxidised liposomes (Van den Berg et al., 1993; Rashba-Step et al., 1997; Van Rossum et al., 2004). There is considerable evidence that oxidatively modified proteins are recognized via carbonyl (Stadtman, 1998) and dityrosine (Giulivi and Davies, 1993) functions or by poly-ubiquitination (Iwai et al., 1998) and degraded proteolytically by proteases, including a $\mathrm{Ca}^{2+}$ dependent protease, acid protease (cathepsin B) and the multicatalytic protease, i.e. the 20s proteasome (Stadtman, 1998; Grune and Davies, 1997). Despite the cellular antioxidant system oxidative damage to DNA by ROS alone is estimated to amount to $\sim 10,000$ hits per cell per day in healthy humans and up to 100,000 hits in the rat (Ames et al., 1993a). Direct repair of DNA hydroperoxides by glutathione peroxidase has been reported from in vitro studies (Demple and Harrison, 1994; Kanno et al., 1999). Next to this, the base excision repair pathway results in the excision of the oxidized base and repair of the DNA (reviewed by Wilson et al., 2003). So in general once a molecule is 
oxidatively damaged beyond repair, it can be completely degraded and replaced via de novo synthesis. A third line of defense is the induction of apoptosis to remove severely, irreversibly damaged cells in a well-controlled manner.

\section{Regulation of cell cycle progression}

In virtually all cells, the cell cycle is composed of four discrete phases, being the DNA synthesis phase (S phase), the cell division phase ( $\mathrm{M}$ phase) and the gap phases between these two, the G1 phase between $\mathrm{M}$ and $\mathrm{S}$ phases and the G2 phase between $\mathrm{S}$ and $\mathrm{M}$ phases (Fig. 2). Progression through the cell cycle is dependent upon the integration of a large number of intra- and extra-cellular signals that integrate also with intrinsic genetic controls, resulting in several checkpoints in different phases of the cell cycle. These checkpoints include the so-called DNA damage checkpoints: S-checkpoint at G1/S en M-checkpoint at $\mathrm{G} 2 / \mathrm{M}$. At these check points the progression through the cell cycle can be arrested to enable the cell to repair DNA upon damage caused by irradiation or chemicals. During $M$ phase checkpoints have been identified in which the proper passage through mitosis is controlled, such as the attachment of all chromosomes to the mitotic spindle: Sp checkpoint. Of special interest are the checkpoints in G1 phase, which are regulated by external factors, such as growth factor- and cell attachment factors. In these check-

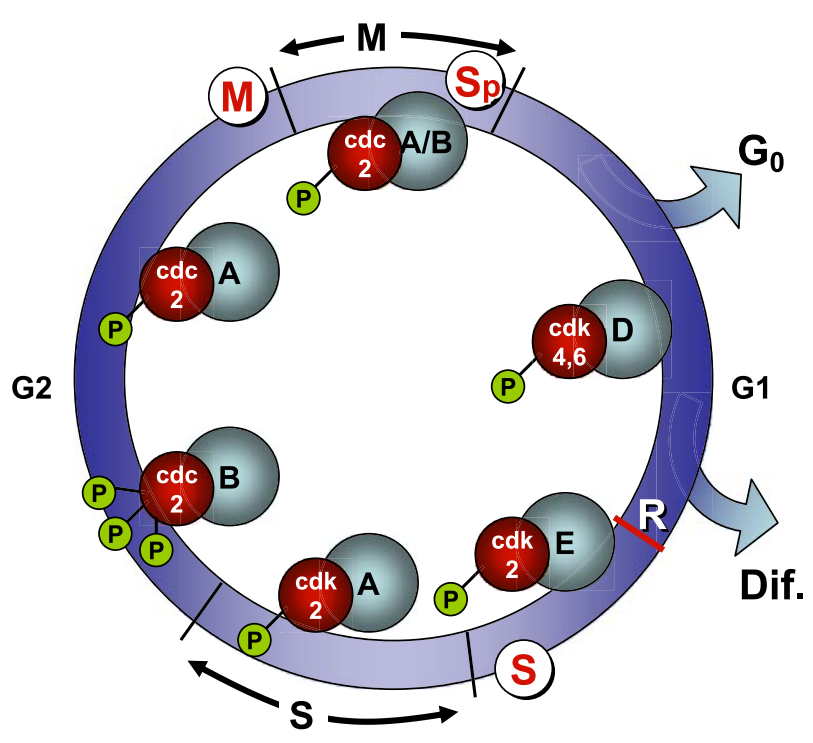

Fig. 2. Overview of the cell cycle of mammalian cells. The mammalian cell cycle basically consists of four phases: first gap phase (G1), DNA synthesis (S), second gap phase (G2) and mitosis (M). The transition between the different phases is regulated by cyclin/CDK complexes. Different cyclins $(\mathrm{A}, \mathrm{B}, \mathrm{D}, \mathrm{E})$ are present during different cell cycle phases and interact with different $C D K s$. $G_{0}$ is the quiescent state., $R$ is the restriction point defined as the point in the G1 phase after which the cells are independent from external factors for progression of the remainder of the cell cycle. S, M and $\mathrm{S}_{\mathrm{p}}$ are checkpoints as described in the text. points the decisions are taken whether the cells continue to progress through the cell cycle, arrest in the quiescent phase (G0), differentiate or undergo apoptosis (for review see Boonstra, 2003a,b).

During the last decades a wealth of knowledge has become available that gives insight in the molecular mechanisms that control cell cycle regulation. Cyclins and their partners the cyclin dependent kinases (CDKs) constitute the basis of these molecular mechanisms. A number of excellent reviews has appeared and describe the mechanisms by which cyclin-CDK activity is regulated in different cell cycle phases (amongst many others: Pines, 1995; Schafer, 1998; Nigg, 1995; Ekholm and Reed, 2000; Norbury and Nurse, 1992; Bird, 2003).

Cyclins are activating subunits that interact with specific CDKs to regulate their activity and substrate specificity. CDKs are serine/threonine protein kinases that require binding of a cyclin in order to be ready to become activated. Mammalian cells contain multiple CDKs that are activated by multiple cyclins (reviewed amongst others in Reed et al., 1994; Pines, 1995; Roussel, 1998; Schafer, 1998; Bird, 2003). CDK activity is regulated by several processes, including phosphorylation on threonine and tyrosine residues; some of these phosphorylation steps being stimulatory, others inhibitory (Obaya and Sedivy, 2002; Bird, 2003). The most important mammalian cyclin-CDK complexes known so far are the mitotic cyclins A and B in association with CDK1, and the G1 cyclins D and E in complex with CDK 4/ 6 and CDK2 (Nigg, 1995; Reed, 1997; Arellano and Moreno, 1997; Sherr, 1995). The first cyclin-CDK complex, to be activated during the G1 phase, is composed of a D-type cyclin in association with CDK4 or CDK6 depending on the cell type (Sherr, 1995). As cells progress through the G1 phase, cyclin E is synthesized with a peak late in G1. Cyclin $\mathrm{E}$ associates with CDK2 and is important for entry into $\mathrm{S}$ phase (Ohtsubo et al., 1995). Once cells enter S phase, cyclin $\mathrm{E}$ is degraded and CDK2 then associates with cyclin A (Fotedar and Fotedar, 1995). Finally, cyclin A and the B-type cyclins associate with CDK1 to promote entry into mitosis. Cyclin A binds to CDK1 with a peak of activity in G2 phase and is then suddenly degraded, whereas entry into mitosis is triggered by cyclin B-CDK1 (Fig. 2). For exit from mitosis, cyclin B destruction is required (Murray, 1995).

An important strategy employed in cell cycle regulation is that one regulatory molecule stimulates one cell cycle phase and inhibits simultaneously another. Thus for example cyclin-CDK activities required for G1/S phase transitions inhibit the G2/M phase transition. This strategy ensures that cell cycle progression is irreversible. This irreversible character of cell cycle progression is even reinforced by ubiquitin-mediated proteolysis of cyclins once a checkpoint has been passed (Koepp et al., 1999). Cyclins all contain a PEST sequence, which is recognized by the appropriate Fbox protein and targets them for ubiquitination and subsequent proteolytic degradation (Schafer, 1998; King et al., 1996). 
In addition, cell cycle progression has been demonstrated to be largely dependent on the activity of CDK inhibitor proteins (CKI) (Tyner and Gartel, 2003). Based on their structures and affinities two families of CKIs have been identified. Members of the Cip/Kip family inhibit CDK2 while members of the INK family inhibit CDK4 and CDK6 (for detailed information, see Tyner and Gartel, 2003; Sherr and Roberts, 1999; Vidal and Koff, 2000). The Cip/Kip CKIs may positively and negatively regulate cyclin/CDK complexes by promoting their assembly and/or stabilization, and inhibiting their activities (see Tyner and Gartel, 2003). The INK4 CKIs inhibit CDK4 directly by binding and CDK2 indirectly by displacing Cip/Kip proteins from cyclin $\mathrm{D}$ containing complexes. The displaced Cip/Kip proteins are then able to bind CDK2 and inhibit its activity (see Tyner and Gartel, 2003).

One of the most important G1 phase cyclin/CDK substrates in mammalian cells is the product of the retinoblastoma tumor suppressor gene (pRB) (Yee and Wang, 2003). $\mathrm{pRB}$ is phosphorylated in a cell cycle dependent manner and binds in the hypophosphorylated state to transcription factors, particularly members of the E2F family. E2F consists of at least five different isoforms that form heterodimers with a second group of proteins known as DP1 (Yee and Wang, 2003). pRB is present in this hypophosphorylated form during early G1 and becomes phosphorylated on several residues during mid to late G1. This phosphorylation causes the release and activation of the E2F transcription factors, allowing transcription of genes that mediate progression through S phase (DeGregori et al., 1995). Initial activation of $\mathrm{pRB}$ is thought to occur in the G1 phase by phosphorylation by cyclin D/CDK complexes. Dtype cyclins can bind directly to pRB in the absence of a kinase, and thus might target the pRB to CDK4/CDK6 kinases. After the initial phosphorylation by cyclin D/CDK, cyclin E/ CDK2 complexes are thought to subsequently phosphorylate $\mathrm{pRB}$ late in G1, thereby triggering the onset of S phase (DeGregori et al., 1995).

Another important protein involved in cell cycle regulation is p53. Under normal conditions the levels of p53 protein are low due to the relatively short half-life of the protein. However, intracellular and extracellular stress signals can induce the stabilization and activation of p53 (Levine, 1997; Cinti et al., 2003). The activation of p53 leads to the transcription of several genes whose products can influence cell cycle progression, such as the CKI $\mathrm{p} 21^{\mathrm{Cip} 1 / \mathrm{WAF} 1}$. Of special interest appears the increase of p53 activity upon DNA damage, resulting in cell cycle arrest and subsequent DNA repair (Cinti et al., 2003).

Cell cycle progression of mammalian cells is determined to a large extent on extracellular signal molecules as growth factors, and to attachment to the extracellular matrix components (for review see Hulleman and van Rossum, 2003; Hulleman and Boonstra, 2001; Juliano, 2003). Interestingly these extracellular signal molecules exert their effect on the cells primarily during the G1 phase of the cell cycle. Growth factors bind and activate either receptors with an intrinsic protein tyrosine kinase activity or receptors that transmit signals to the cytoplasm by interacting with GTP-binding proteins (G-proteins). Activation of these receptors subsequently results in the activation of intracellular signal transduction networks, which ultimately result in cell proliferation. These networks include the MAP kinase pathway, amongst others, and this pathway has been demonstrated to play an essential role in progression through the G1 phase of the cell cycle (Hulleman et al., 1999; Hulleman and van Rossum, 2003).

\section{ROS and cell cycle progression}

ROS cause a wide range of adaptive cellular responses ranging from transient growth arrest to permanent growth arrest, to apoptosis or to necrosis, dependent on the level of ROS. These responses to allow organisms to remove damage caused by ROS or allow organisms to remove damaged cells. In addition however, low levels of ROS have been demonstrated to cause an increase in cell cycle progression, in this latter case ROS have usually an endogenous origin (Martindale and Holbrook, 2002; Davies, 2000). In the following sections we will discuss the effects of ROS on various cellular processes involved in cell cycle control.

\subsection{Effect of ROS on signal transduction}

Although the biological production of oxygen free radicals has been known for a long time, the effects of oxidative stress on signal transduction and cellular functioning have only been studied widely for the last decade.

\subsubsection{ROS and phosphorylation/dephosphorylation pathways}

Various studies have established that oxygen free radicals can cause the phosphorylation and activation of numerous signaling proteins (Finkel and Holbrook, 2000), including Receptor Tyrosine Kinases (RTK) (Gamou and Shimizu, 1995; González-Rubio et al., 1996), PKC (Gopalakrishna and Jaken, 2000), PLC 11 (Schieven et al., 1993), Src kinases (Aikawa et al., 1997; Hardwick and Sefton, 1997), MAPKs (Dérijard et al., 1994; Stevenson et al., 1994; De Wit et al., 1998; Bapat et al., 2001), protein kinase B (Wang et al., 2000), and transcription factors (Devary et al., 1991; Meyer et al., 1993). As an example the effects on the RTK and MAPK pathway will be discussed. Exposure of cells to $\mathrm{ONOO}^{-}$or $\mathrm{H}_{2} \mathrm{O}_{2}$ induces phosphorylation of the PDGF receptor and the EGF receptor (Gamou and Shimizu, 1995; González-Rubio et al., 1996; Knebel et al., 1996; Zhang et al., 2000) suggesting that oxygen free radicals initiate signaling events that mimick those induced by growth factors. This was confirmed by the observation that the $\mathrm{H}_{2} \mathrm{O}_{2}$-induced Tyr phosphorylated EGF receptor forms a 
complex with downstream signaling molecules as Shc, Grb2 and Sos in vascular smooth muscle cells, followed by the activation of $\mathrm{p} 21^{\text {ras }}$ (Rao, 1996). Also the oxidative stressinduced phosphorylation and activation of the Ser/Thr kinase Raf-1, a downstream effector molecule of $\mathrm{p} 21^{\text {ras }}$, has been described in several cell types as well (Kasid et al., 1996; Abe et al., 1998). Other studies have established that oxidative stress induces the phosphorylation and activation of MAPKs (Guyton et al., 1996; Lander et al., 1996; Peus et al., 1999a; Dérijard et al., 1994; Stevenson et al., 1994; Zhang et al., 2000; De Wit et al., 1998; Bapat et al., 2001).

Activation of $\mathrm{p} 42 / \mathrm{p} 44^{\mathrm{MAPK}}$ by ROS might be due to direct phosphorylation of the upstream kinase MEK, for instance by exposure of cells to $\mathrm{ONOO}^{-}$(Zhang et al., 2000 ). On the other hand, activation of $\mathrm{p} 42 / \mathrm{p} 44^{\mathrm{MAPK}}$ by $\mathrm{H}_{2} \mathrm{O}_{2}$ has been shown to be mediated by the activation of the RTK, PKC, Raf-1 and MEK (Abe et al., 1998), indicating that different ROS might have different targets. Also, the same ROS may have different effects in different cell types, since the activation of MAPK by $\mathrm{ONOO}^{-}$in Rat-1 fibroblasts is MEK-independent (Bapat et al., 2001). Activation of MAPKs by oxygen free radicals has been shown to result in subsequent activation of transcription factors and induction of c-fos and c-jun expression (Schreck et al., 1991; Schmidt et al., 1996; Buscher et al., 1988; Devary et al., 1991; Rao, 1997). This oxidant-induced MAPK activation might be involved in the cellular response to oxidative stress and many studies have indicated that (pharmacological) inhibition of the $\mathrm{p} 42 / \mathrm{p} 44^{\mathrm{MAPK}}$ pathway, $\mathrm{PI} 3-\mathrm{K} / \mathrm{AKT}$ and/or the PLC- $\gamma$ pathway rendered cells more susceptible to hydrogen peroxide. In line with this, molecular cell biological approaches leading to increased activity of these pathways enhance survival upon oxidative stress (reviewed by Holbrook and Ikeyama, 2002).

The effects of oxygen free radicals on signal transduction might be based on normal cell physiology. A variety of ligands, including tumor necrosis factor- $\alpha$ (Meier et al., 1989), interleukin-1 (Meier et al., 1989), transforming growth factor- $\beta 1$ (Ohba et al., 1994), PDGF (Sundaresan et al., 1995), and EGF (Bae et al., 1997), have been demonstrated to result in an increase of ROS upon receptor activation. The generation of oxidants by ligand-receptor interactions resulted in stimulation of signaling molecules and therefore, ROS can be considered to serve as physiologic second messengers in signal transduction. The predominant ROS produced upon EGF and PDGF stimulation appeared to be $\mathrm{H}_{2} \mathrm{O}_{2}$ (Sundaresan et al., 1995; Bae et al., 1997, 2000; Peus et al., 1999b) and elimination of $\mathrm{H}_{2} \mathrm{O}_{2}$ by incorporation of catalase was shown to inhibit EGF-induced Tyr phosphorylation of various signaling proteins including the EGF receptor (Bae et al., 1997). In addition, it was shown that EGF-induced $\mathrm{H}_{2} \mathrm{O}_{2}$ production required intrinsic RTK activity, but probably not the C-terminal autophosphorylation sites of the EGF receptor (Bae et al., 1997). As a source for the RTK induced ROS production a membrane bound NADPH oxidase is proposed, which, upon activation via the small GTPase Rac1 catalyzes the formation of $\mathrm{O}_{2}^{\mathbf{}^{-}}$ (Bae et al., 1997, 2000; Chiarugi and Cirri, 2003).

Both the activation of Tyr kinases and the inactivation of Tyr phosphatases (PTPs) have been proposed to be involved in the activation of signaling cascades by ROS. In the last few years, several studies have shown that exposure of cells to $\mathrm{H}_{2} \mathrm{O}_{2}$, UV radiation or $\mathrm{O}_{2}^{-}$causes the (reversible) inactivation of different PTPs, including LMW-PTPs, RPTP $\alpha$, PTP1B and PTP1C (Sullivan et al., 1994; Caselli et al., 1998; Barrett et al., 1999; Groß et al., 1999). Furthermore, stimulation of A431 cells with EGF resulted in a reversible inactivation of PTP1B (Lee et al., 1998). The PTPs that are affected by ROS all seem to share the same catalytic mechanism with a central catalytic Cys. Since SH groups are sensitive to oxidation, increased phosphorylation of signaling proteins by ROS are most likely accomplished by reversible inactivation of PTPs via oxidation of essential SH groups within their active site Cys (Lee et al., 1998; Chiarugi and Cirri, 2003), thereby assuming that the cell maintains spontaneous Tyr kinase activity (Knebel et al., 1996). These studies suggest that ROS, either generated intracellularly in response to EGF or added extracellularly, act as second messengers in signal transduction and activate signaling pathways by the same mechanisms.

Recently it was shown that not only the activation of Tyrosine Kinase receptors results in an increase in cellular ROS production, but also the activation of integrins leads to ROS production (Honore et al., 2003; Chiarugi et al., 2003).This ROS production is suggested to be mediated by cytosolic lipoxygenase and is an essential mediator for cell adhesion by oxidative inhibition of FAK tyrosine phosphatase (Chiarugi et al., 2003). Activation of the $\alpha_{2} \beta_{1}$-integrin receptor in CaCo-2 cells by collagen IV, in the absence of soluble growth factors, resulted in the production of ROS and subsequent cell cycle progression (Honore et al., 2003).

\subsubsection{ROS and ubiquitin pathway}

As stated earlier, ubiquitin mediated degradation of the cyclins plays an important role in cell cycle regulation and for that reason it is important to know how oxidative stress affects the ubiquitination system and the subsequent proteosomal degradation of the ubiquitinated proteins. Exposure of bovine retina cells or bovine lens epithelial cells to $\mathrm{H}_{2} \mathrm{O}_{2}$ results in a rapid and dose-dependent loss of endogenous ubiquitin-protein conjugates and was consistent with reductions in ubiquitin-activating enzyme (E1) and ubiquitin-conjugating enzyme (E2) activities (Shang and Taylor, 1995; Jahngen-Hodge et al., 1997). Oxidative stress results in oxidation of glutathione (GSH), leading to the formation of GSSG and subsequent formation of mixed disulfides between glutathione and the cysteines of several proteins (Fratelli et al., 2003). Indeed the decreased E1 and E2 activities were inversely related with the cellular ratio of GSSG:GSH and therefore, it was proposed that increases in the cellular ratio of GSSG:GSH resulted in a rapid $S$ - 
thiolation of E1 and E2 active-site sulphydryls by GSSG (Jahngen-Hodge et al., 1997; Obin et al., 1998). $\mathrm{H}_{2} \mathrm{O}_{2}$ also prevented in a reversible manner ubiquitination of the EGF receptor and EPS 15, which again coincides with a reversible increase in the ratio of GSSG:GSH (De Wit et al., 2001). The formation of the mixed disulfides is reversible and restoration of the GSSG:GSH ratio upon recovery from the oxidative stress will result in restoration of the free $\mathrm{SH}$ group of the cystein(s) involved. Accordingly, $\mathrm{H}_{2} \mathrm{O}_{2}$ treatment resulted in a sustained expression of cyclins D1 and D2, caused by a transient inhibition of the ubiquitination process and/or the proteasome activity (Martínez Muñoz et al., 2001). Not only the ubiquitination process, but also the proteasome itself was inhibited by oxidative stress (Reinheckel et al., 1998; Szweda et al., 2002).

Next to an inhibition of the ubiquitination pathway, due to the immediate effect of ROS via GSSG, an increase in certain ubiquitin conjugating enzymes is observed during prolonged incubations. The increased activity of these enzymes in skeletal muscle cells occurred 4 hours after the application of $\mathrm{H}_{2} \mathrm{O}_{2}$ and needed both transcriptional and translational activity, suggesting that oxidative signaling induces a subset of redox sensitive genes coding for ubiquitin and ubiquiting conjugating enzymes (Li et al., 2003).

\subsubsection{ROS and the cytoskeleton}

Activation of growth factor receptors results amongst others in a reorganization of the actin cytoskeleton, resulting in altered cell morphology and the recruitment of signaling molecules to specific sites in the cells (Diakonova et al., 1995). Also during the $\mathrm{G} 2 / \mathrm{M} / \mathrm{G} 1$ transition major changes occur in cell morphology as a consequence of changes in the actin microfilament system. The changes in the actin cytoskeleton occurring during the flattening of the rounded $\mathrm{M}$ phase cells, is clearly inhibited by $\mathrm{H}_{2} \mathrm{O}_{2}$ (Martínez Muñoz et al., 2002). The way ROS affect the actin microfilaments may occur indirectly via the activation of the above mentioned signal transduction pathways (Huot et al., 1997; Irani and Goldschmidt-Clermont, 1998; Dalle-Donne et al., 2002) or directly via the formation of $S$-thiolation of actin (Wang et al., 2001; Chai et al., 1994; Dalle-Donne et al., 2002). The latter paper showed that glutationylation of actin by GSSG strongly decreases the actin polymerization rate. There are clear indications that endogenously produced ROS, again via NADPH oxidases, stimulated by Rac, are important mediators of actin cytoskeleton remodeling (Irani and Goldschmidt-Clermont, 1998; Moldovan et al., 1999). Also microtubules are affected by oxidative stress and PKC$\delta$ is required for oxidant induced loss of microtubule cytoskeletal assembly (Banan et al., 2002).

\subsection{Effect of ROS on regulators of cell cycle progression}

As described above, controlled cell cycle progression requires the precise integration of many different processes in cells, including the signal transduction cascades activated by mitogens and the extracellular matrix, the ubiquitination processes and subsequent degradation of proteins in the proteasome and the proper (re-)organization of the cytoskeleton, in particular actin and tubulin, amongst many others. Since it has been demonstrated that ROS influence many of these processes, it is obvious that ROS influence cell cycle progression. The ultimate/specific effect of ROS on cell cycle progression is however difficult to predict due to the complex nature of the effects of ROS on different cellular processes. This includes the complex nature of the molecular network that regulates cell cycle progression, the site in the cell where ROS is produced, and the type of ROS produced.

One of the first observations of the cellular response to oxygen-induced cytotoxicity was decreased proliferation in HeLa cells (Rueckert and Mueller, 1960). Several studies since then have demonstrated that hyperoxia induces inhibition of proliferation in G1, S and G2 phases of the cell cycle (Rancourt et al., 1999; Shenberger and Dixon, 1999; Helt et al., 2001; Rancourt et al., 2001). Recent studies indicate that the arrest in G1 phase is related to protection of cells against oxidative damage and cell death (Rancourt et al., 2002). In other studies it was shown that sublethal doses of $\mathrm{H}_{2} \mathrm{O}_{2}$ induced senescence-like permanent cell cycle arrest in G1 phase in human fibroblasts (Chen et al., 1998; 2000). In contrast, sublethal doses of $\mathrm{H}_{2} \mathrm{O}_{2}$ caused a transient arrest in NIH 3 T3 fibroblasts (Barnouin et al., 2002). In this latter case cells were arrested in all phases of the cell cycle, except for the $\mathrm{M}$ phase. A decrease in cell cycle progression due to $\mathrm{H}_{2} \mathrm{O}_{2}$ was also observed in $\mathrm{CHO}$ cells when $\mathrm{H}_{2} \mathrm{O}_{2}$ was added to the cells during the $\mathrm{M}$ phase (Martínez Muñoz et al., 2002). In these cells the cell cycle inhibition was accompanied by inhibition of cell spreading, focal adhesion formation and stress fiber formation during early G1 phase. Furthermore, $\mathrm{H}_{2} \mathrm{O}_{2}$ caused a reversible inhibition of the ubiquitin-proteosome dependent degradation of cyclin D1 and D2 in HER14 fibroblasts (Martínez Muñoz et al., 2001). Exposure of the oligodendrocyte cell line CG4 to various amounts of $\mathrm{H}_{2} \mathrm{O}_{2}$ resulted in stimulation of the PGDF receptor kinase and various MAP kinase pathways including ERK, p38 MAPK and c-Jun N-terminal kinase (JNK) and in cell death (Bhat and Zhang, 1999). In contrast, $\mathrm{H}_{2} \mathrm{O}_{2}$ generation by PDGF was involved in tyrosine phosphorylation and mitogenesis in vascular smooth muscle cells (Irani et al., 1997). Apparently, both cell proliferation and growth arrest have been observed after oxidative stress, dependent upon the cell type, while the growth arrest may occur in G1, S or G2 phases and may be transient or permanent and in the latter case may end with apoptosis or even necrosis.

However, despite the complex nature of the effects of ROS on cell cycle progression at moderate ROS concentrations, a common component seems to play an important role (see Fig. 1). This common component appears the induction of the cyclin kinase inhibitor $\mathrm{p} 21^{\mathrm{Cip} 1} \cdot \mathrm{p} 21^{\mathrm{Cip} 1}$ belongs to the family of Cip/Kip proteins which contains a 
conserved region of sequence at the amino acid terminus that is required and sufficient for the inhibition of cyclin/ CDK complexes. Although initially identified as a CDK inhibitor, p21 has been also demonstrated to stabilize interactions between cyclin D and CDK4 and thus promote the formation of active complexes (LaBaer et al., 1997). Expression of p21 is induced following DNA damage and detected in differentiated cells and is induced by a number of mitogenic stimuli (Tyner and Gartel, 2003). In addition p21 contains a carboxy terminal binding site for proliferating cell nuclear antigen (PCNA), and by this interaction $\mathrm{p} 21$ is able to block DNA synthesis by DNA polymerase $\delta$. Several studies have suggested that $\mathrm{p} 21$ regulates DNA repair by its interaction with PCNA and with cyclin-CDK complexes, although its precise role has not been established (Tyner and Gartel, 2003). Of particular interest appears the recent observation that $\mathrm{p} 21$ is involved in the organization of the actin microfilament system by inhibiting the Rho kinase (Lee and Helfman, 2004). p21 expression has been demonstrated to be regulated at the transcriptional level by both $\mathrm{p} 53$-dependent and -independent mechanisms, and at the post-transcriptional level by both ubiquitin-dependent and -independent proteasomal mediated degradation (for review, see Tyner and Gartel, 2003). The p53-dependent induction of p21 has been related usually to DNA damage. DNA strand breaks lead to the activation of ATM, a PI3 kinase related kinase. ATM on its turn results in the activation and stabilization of $\mathrm{p} 53$, which in turn induces p21 (Cinti et al., 2003). In addition to p53, a number of transcription factors have been demonstrated to cause $\mathrm{p} 21$ transcription, including Sp1, Sp3, Ap2, STATs, C/EBP $\alpha, \mathrm{C} /$ EBP $\beta$ and others (for review, see Gartel and Tyner, 1999; Lavrovsky et al., 2000).

Studies using SV40-immortalized rat type II pulmonary epithelial cells revealed that oxygen-induced inhibition of cell proliferation was associated with induction of transforming growth factor (TGF) $\beta 1$ and $\mathrm{p} 21^{\mathrm{Cip} 1}$ (Corroyer et al., 1996). Furthermore, treatment of HELA cells with diethylmaleate (DEM), a glutathione-depleting agent, resulted also in induction of p21 (Esposito et al., 1998). Sublethal doses of $\mathrm{H}_{2} \mathrm{O}_{2}$ caused a transient arrest in NIH 3T3 fibroblasts which was associated with a decrease of cyclin D1 and cyclin D3 expression and a concomitant increase in $\mathrm{p} 21^{\mathrm{Cip} 1}$ expression (Barnouin et al., 2002). An increase in p21 expression and a G1 phase arrest was also found in murine lung cells during hyperoxia (McGrath, 1998). Furthermore it was demonstrated that nitric oxide caused a G1 phase arrest in human pancreatic carcinoma cell lines, again accompanied by an increase in p21 expression (Gansauge et al., 1998). This G1 arrest was followed by apoptosis. In contrast a reversible cell cycle inhibition upon exposure of human hepatocellular carcinoma cells to nitric oxide was observed, also accompanied with increased expression of p21 (Esumi et al., 1997). Nitric oxide caused a G1 arrest with elevated levels of p21 in vascular smooth muscle cells. In these cells an inhibition was determined of
CDK2 activity and of RB phosphorylation (Ishida et al., 1997).

Upregulation of $\mathrm{p} 21$ has been demonstrated to cause senescence in various cell types and that process was inhibited by antioxidants (Macip et al., 2002). The role of p21 in ROS was shown to be independent of the PCNA and cyclin related functions of p21 (Macip et al., 2002). In human fibroblasts an increase in endogenous ROS, caused by the reduction of GSH by diethylmaleate, induced the expression of $\mathrm{p} 21^{\mathrm{Cip} 1}$ and subsequent G1 arrest (Russo et al., 1995). In T47D-H3 human carcinoma cells, which contain mutated $\mathrm{p} 53$, an S-phase arrest was observed after hypoxia, associated with acute inhibition of CDK2 activity and DNA synthesis (Bilodeau et al., 2000). This cell cycle arrest was prevented by an increase of the peroxide scavenging capacity via glutathione peroxidase-1 (Bilodeau et al., 2002). Hyperoxia $\left(95 \% \mathrm{O}_{2}, 5 \% \mathrm{CO}_{2}\right)$ caused an increase in $\mathrm{p} 53$ expression and $\mathrm{p} 53$ phosphorylation and $\mathrm{p} 21 \mathrm{mRNA}$ and protein expression and cell cycle arrest in HCT116 colon carcinoma cells. In contrast no effects on p21 expression was observed in either p53- or p21-deficient cells, indicating the essential role of p53 in p21-induced cell cycle arrest. Furthermore, the cells containing p21 were demonstrated to resume proliferation after recovery, in contrast to p21 deficient cells (Helt et al., 2001).

Several studies have demonstrated that ROS caused a G2/M arrest (Thorn et al., 2001; Chung et al., 2002; Zhang et al., 2001, 2003; Bijur et al., 1999). In these cases elevation of ROS was demonstrated to result in p53-independent accumulation of $\mathrm{p} 21$, in an increase in expression of Chk1 and decrease in Cdc25c. This latter phosphatase causes dephosphorylation of cdc2 under normal conditions and hence an activation of the mitotic cyclin-CDK complexes. This effect of ROS during G2 phase was accompanied by an increase in both ERK and p38 phosphorylation (Zhang et al., 2003). Furthermore, the effects of ROS on p21, Chk1 and Cdc25d expression was shown to be dependent on both ERK and p38 activity (Zhang et al., 2003).

The brief description of the effects of ROS on cell cycle progression clearly indicates that $\mathrm{p} 21$ plays a prominent role. In this respect especially the AP-1 and Sp1-mediated induction of $\mathrm{p} 21$ is of interest. The transcription factor AP-1 consists of 2 subunits, at least one of them is a member of families of DNA-binding proteins Jun or Fos (for review, see Eferl and Wagner, 2003). The other subunit of AP-1 can be a member of the activation transcription factor (ATF) family. The subunit composition determines the affinity of AP-1 to the operator DNA sequence and hence its interaction with other transcription factors and the final activity. AP-1 is activated by various effectors, including growth factors, cytokines, hormones and oxidative stress, amongst many others. ROS activates AP-1 through the activation of JNK, this kinase phosphorylates and activates c-Jun and ATF-2 components of AP-1. Sp1 is also a transcription factor that has been demonstrated to be influenced by oxidative stress and which is able to induce p21 (Eferl 
and Wagner, 2003; Kim et al., 2003). In addition, ROS cause also activation of ERK (see above) which on its turn results in activation of the transcription factors c-Ets and cElk. These two transcription factors are required for expression of c-fos and JunB, which are also constituents of AP-1 (Turpaev, 2002). Thus in many cases ROS induce AP-1 activity leading amongst others to the expression of $\mathrm{p} 21$. Clearly these effects are independent of p53 and of the PCNA-binding property of $\mathrm{p} 21$.

As described above, ROS have a multitude of effects on signal transduction and cell cycle progression, the ultimate effect depending upon the amount of ROS, the type of reactive oxygen species, the duration of exposure of the cells to ROS and to the cell type involved. Considering these variables, the following picture, as shown in Fig. 3, emerges from these studies. We suggest that short exposure of non-proliferating cells to relatively low doses of ROS results in an activation of signal transduction pathways comparable to the effects of mitogens, and these low doses of ROS may cause a proliferation of these non-proliferating cells. If proliferating cells are exposed to such low doses ROS for a short time, the proliferation rate may increase. If proliferating cells are exposed to relatively low doses of
ROS for a prolonged period of time, the signal transduction pathways are activated for a long period of time as well, and this situation seems comparable to the effects of differentiation factors, such as the nerve growth factor. Sustained activation of signal transduction, as has been demonstrated for the MAPK pathway, results in arrest of cell proliferation in the G1 phase of the cell cycle and a sustained expression of some of the cyclin D isoforms. Such a G1 arrest has been demonstrated to occur in cells subjected to prolonged exposure of ROS. Depending upon the cellular localization of the ROS, increased amounts of ROS may cause damage of DNA, which will result in induction of p53 activity and consequently in expression of $\mathrm{p} 21$. In these cases cell proliferation will be stopped in all phases of the cell cycle and during this arrest DNA repair will occur after which cell proliferation will resume. Alternatively, exposure to increased amounts of ROS may also result in a p53-independent expression of $\mathrm{p} 21$, due to the AP-1 or Sp1 site of the p21 promoter, which is redox sensitive. A recovery of the cellular redox state will eventually result in normalization of p21 levels and allow the cells to escape from the transient cell cycle arrest. Prolonged activation of AP-1 will cause the cells to arrest their cell cycle in all cell cycle phases. If the

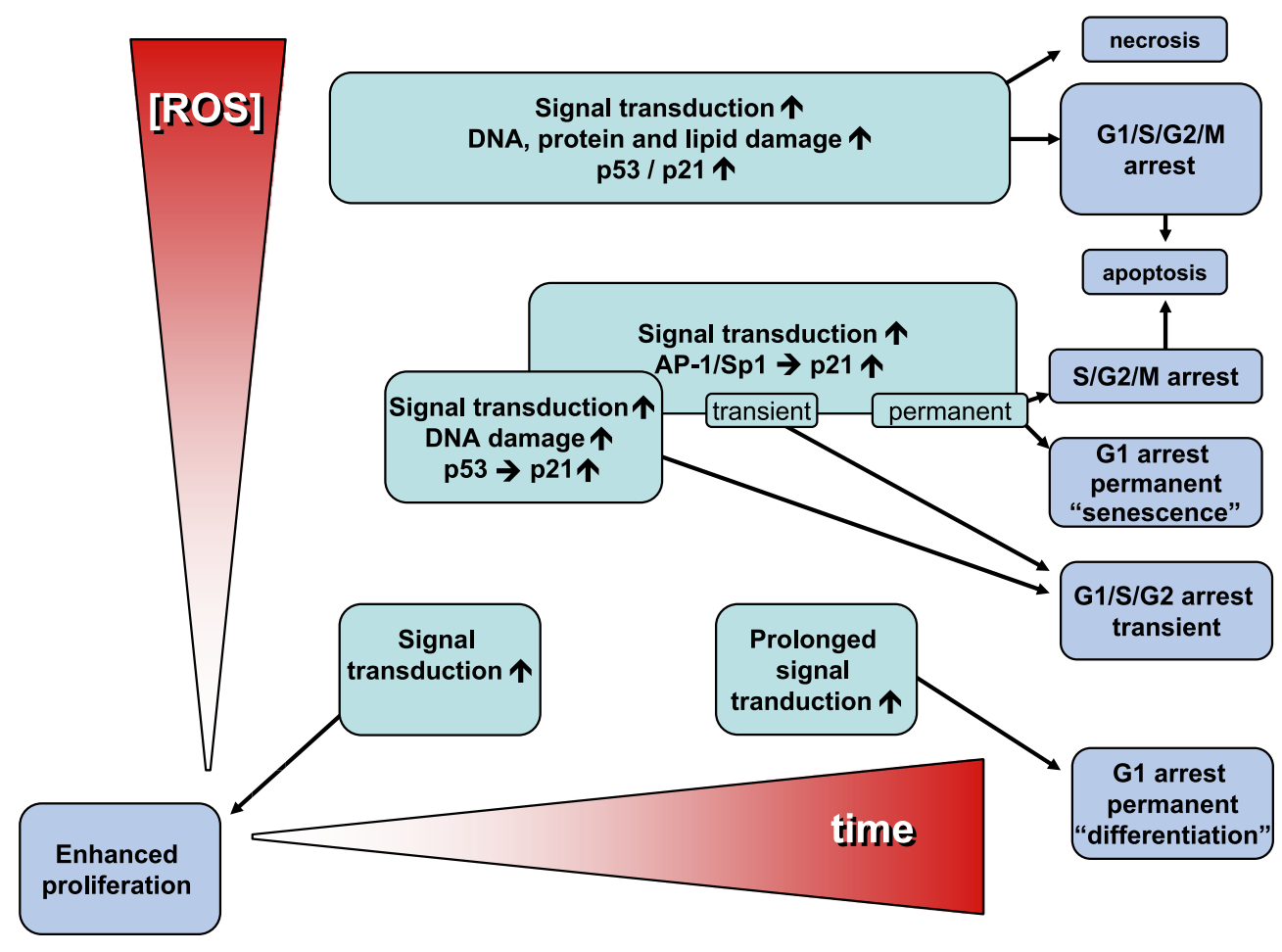

Fig. 3. Scheme, representing the multitude of effects that ROS can have on signal transduction and cell cycle progression. For a given cell and ROS type the effects depend on the amount of ROS and the duration of exposure of the cells to ROS. A short exposure to relatively low doses results in an activation or enhancement of signal transduction pathways leading to (enhanced) cell proliferation. Prolonged exposure to these ROS concentrations will result in prolonged activation of these signal transduction pathways, comparable to the effects of differentiation factors, which will result in a G1 arrest. At higher concentrations and possibly depending on the cellular localization of the ROS, damage to DNA might occur, resulting in an induction of p53 activity and consequently in expression of p21. During the subsequent cell cycle arrest DNA repair will occur after which cell proliferation will resume. Alternatively p21 may become expressed due to the AP-1 or Sp1 sites, which are redox sensitive, resulting in a transient or permanent G1 arrest. If the amounts of ROS are again higher, either due to increase concentrations or prolonged exposure, all changes described above will take place, together with structural damage to proteins and lipids. Under these conditions, cells will arrest in all phases of the cell cycle, especially in the G1 and G2 phases and the cells will undergo apoptosis. Upon sever damage the cells may directly undergo necrosis. 
cell arrests in G1 phase, the cells stay viable and growth arrest appears permanent. These cells are in a senescent-like state. If the cells arrest in S, G2 or M phase, the cells will presumably undergo apoptosis in due time. If the amounts of ROS are again higher, not only signal transduction is activated and $\mathrm{p} 21$ expression is increased, but also processes in the cells are affected such as ubiquitination, essential for cyclin function, proteasomal degradation and protein and lipid oxidation. Under these conditions, cells will arrest in all phases of the cell cycle, especially in the G1 and G2 phases and the cells will undergo apoptosis or in severe cases even necrosis.

\section{Acknowledgements}

We would like to thank our (former) co-workers for their contributions. Due to space constraints and the huge body of literature, we have been unable to cite all original papers. We therefore apologize to authors whose work on this subject area may have been omitted.

\section{References}

Abe, M.K., Kartha, S., Karpova, A.Y., Li, J., Liu, P.T., Kuo, W.-L., Hershenson, M.B., 1998. Hydrogen peroxide activates extracellular signalregulated kinase via protein kinase C, Raf-1, and MEK1. Am. J. Respir. Cell Mol. Biol. 18, 562-569.

Adams, D.O., Johnson, W.J., Marino, P.A., 1982. Mechanisms of target recognition and destruction in macrophage-mediated tumor cytotoxicity. Fed. Proc. 41, 2212-2221.

Aikawa, R., Komuro, T., Zou, Y., Kudoh, S., Tanaka, M., Shiojima, I., Hiroi, Y., Yazaki, Y., 1997. Oxidative stress activates extracellular signal-regulated kinases through Src and Ras in cultured cardiac myocytes of neonatal rats. J. Clin. Invest. 100, 1813-1821.

Ames, B.N., Shigenaga, M.K., Gold, L.S., 1993a. DNA lesions, inducible DNA repair, and cell division: three key factors in mutagenesis and carcinogesis. Environ. Health Perspect. 101 (Suppl. 5), 35-44.

Ames, B.N., Shigenaga, M.K., Hagen, T.M, 1993b. Oxidants, antioxidants, and the degenerative diseases of aging. Proc. Natl. Acad. Sci. U. S. A. 90, 7915-7922.

Arellano, M., Moreno, S., 1997. Regulation of CDK/cyclin complexes during the cell cycle. Int. J. Biochem. Cell Biol. 29, 559-573.

Bae, Y.S., Kang, S.W., Seo, M.S., Baines, I.C., Tekle, E., Chock, P.B., Rhee, S.G., 1997. Epidermal growth factor (EGF)-induced generation of hydrogen peroxide. Role in EGF receptor-mediated tyrosine phosphorylation. J. Biol. Chem. 272, 217-221.

Bae, Y.S., Sung, J.-Y., Kim, O.-S., Kim, Y.J., Hur, K.C., Kazlauskas, A., Rhee, S.G., 2000. Platelet-derived growth factor-induced $\mathrm{H}_{2} \mathrm{O}_{2}$ production requires the activation of phosphatidylinositol 3-kinase. J. Biol. Chem. 275, 10527-10531.

Banan, A., Fields, J.Z., Farhadi, A., Talmage, D.A., Zhang, L., Keshavarzian, A., 2002. Activation of delta-isoform of protein kinase $\mathrm{C}$ is required for oxidant-induced disruption of both the microtubule cytoskeleton and permeability barrier of intestinal epithelia. J. Pharmacol. Exp. Ther. 303, 17-28.

Bapat, S., Verkleij, A.J., Post, J.A., 2001. Peroxynitrite activates mitogenactivated protein kinase (MAPK) via a MEK-independent pathway: a role for protein kinase C. FEBS Lett. 499, 21-26.

Barnouin, K., Dubuisson, M.L., Child, E.S., Fernandez de Mattos, S., Glassford, J., Medema, R.H., Mann, D.J., Lam, E.W.-F., 2002. $\mathrm{H}_{2} \mathrm{O}_{2}$ induces a transient multi-phase cell cycle arrest in mouse fibroblasts through modulating cyclin D and $21^{\text {Cip1 }}$ expression. J. Biol. Chem. 277, 13761-13770.

Barrett, W.C., DeGnore, J.P., Keng, Y.-F., Zhang, Z.-Y., Yim, M.B., Chock, P.B., 1999. Roles of superoxide radical anion in signal transduction mediated by reversible regulation of protein-tyrosine phosphatase $1 \mathrm{~B}$. J. Biol. Chem. 274, 34543-34546.

Baynes, J.W., 2001. The role of AGEs in aging: causation or correlation. Exp. Gerontol. 36, 1527-1537.

Bhat, N.R., Zhang, P., 1999. Hydrogen peroxide activation of multiple mitogen-activated protein kinases in an oligodendrocyte cell line: role of extracellular signal-regulated kinase in hydrogen peroxide-induced cell death. J. Neurochem. 72, 112-119.

Bijur, G.N., Briggs, B., Hitchcock, C.L., Williams, M.V., 1999. Ascorbic acid-dehydroascorbate induces cell cycle arrest at $\mathrm{G}_{2} / \mathrm{M}$ DNA damage checkpoint during oxidative stress. Environ. Mol. Mutagen. 33, $144-152$.

Bilodeau, J.F., Faure, R., Piedboeuf, B., Mirault, M.E., 2000. Hyperoxia induces S-phase cell-cycle arrest and p21 ${ }^{\text {Cip1/Wafl }}$-independent CDK2 inhibition in human carcinoma T47D-H3 cells. Exp. Cell Res. 256, 347-357.

Bilodeau, J.F., Patenaude, A., Piedboeuf, B., Carrier, C., Petrov, P., Faure, R., Mirault, M.E., 2002. Glutathione peroxidase -1 expression enhances recovery of human breast carcinoma cells from hyperoxide cell cycle arrest. Free Radic. Biol. Med. 33, 1279-1289.

Bird, R.C., 2003. Role of cyclins and cyclin-dependent kinases in G1 phase progression. In: Boonstra, J. (Ed.), G1 Phase Progression. Kluwer Academic/Plenum, New York, pp. 40-57. ISBN: 0-306-47831-5.

Boonstra, J., 2003a. Progression through the G1-phase of the on-going cell cycle. J. Cell. Biochem. 90, 244-252.

Boonstra, J., 2003b. Restriction points in the G1 phase of the mammalian cell cycle. In: Boonstra, J. (Ed.), G1 Phase Progression. Kluwer Academic/Plenum, New York, pp. 1-13. ISBN: 0-306-47831-5.

Buscher, M., Rahmsdorf, H.J., Liftin, M., Karin, M., Herrlich, P., 1988. Activation of the c-fos gene by UV and phorbol ester: different signal transduction pathways converge to the same enhancer element. Oncogene 3, 301-311.

Caselli, A., Marzocchini, R., Camici, G., Manao, G., Moneti, G., Pieraccini, G., Ramponi, G., 1998. The inactivation mechanism of low molecular weight phosphotyrosine-protein phosphatase by $\mathrm{H}_{2} \mathrm{O}_{2}$. J. Biol. Chem. 273, 32554-32560.

Cerutti, P.A., 1985. Pro-oxidant states and tumor promotion. Science 227, 375-381.

Chai, Y.C., Ashraf, S.S., Rokutan, K., Johnston Jr., R.B., Thomas, J.A., 1994. S-thiolation of individual human neutrophil proteins including actin by stimulation of the respiratory burst: evidence against a role for glutathione disulfide. Arch. Biochem. Biophys. 310, $273-281$.

Chen, Q.M., Bartholomew, J.C., Campisi, J., Acosta, M., Reagan, J.D., Ames, B.N., 1998. Molecular analysis of $\mathrm{H}_{2} \mathrm{O}_{2}$-induced senescent-like growth arrest in normal human fibroblasts: $\mathrm{p} 53$ and $\mathrm{Rb}$ control $\mathrm{G}_{1}$ arrest but not cell replication. Biochem. J. 332, 43-50.

Chen, Q.M., Liu, J., Merrett, J.B., 2000. Apoptosis or senescence-like growth arrest: influence of cell-cycle position, p53, p21 and bax in $\mathrm{H}_{2} \mathrm{O}_{2}$ response of normal human fibroblasts. Biochem. J. 347, 543-551.

Chiarugi, P., Cirri, P., 2003. Redox regulation of protein tyrosine phosphatases during receptor tyrosine kinase signal transduction. Trends Biochem. Sci. 28, 509-514.

Chiarugi, P., Pani, G., Giannoni, E., Taddei, L., Colavitti, R., Raugei, G., Symons, M., Borrello, S., Galeotti, T., Ramponi, G., 2003. Reactive oxygen species as essential mediators of cell adhesion: the oxidative inhibition of a FAK tyrosine phosphatase is required for cell adhesion. J. Cell Biol. 161, 933-944.

Chung, Y.W., Jeong, D.W., Won, J.Y., Choi, E.-J., Choi, Y.H., Kim, I.Y., 2002. $\mathrm{H}_{2} \mathrm{O}_{2}$-induced AP-1 activation and its effect on p21 WAF1/CIP1mediated $\mathrm{G} 2 / \mathrm{M}$ arrest in a p53-deficient human lung cancer cell. Biochem. Biophys. Res. Commun. 293, 1248-1253.

Cinti, C., Trimarchi, C., Giordano, A., 2003. G1 phase progression and 
apoptosis. In: Boonstra, J. (Ed.), G1 Phase Progression. Kluwer Academic/Plenum, New York, pp. 199-235. ISBN: 0-306-47831-5.

Cooke, M.S., Evans, M.D., Dizdaroglu, M., Lunec, J., 2003. Oxidative DNA damage: mechanisms, mutations and disease. FASEB J. 17, 1195-1214.

Corroyer, S., Maitre, B., Cazals, V., Clement, A., 1996. Altered regulation of G1 cyclins in oxidant-induced growth arrest of lung alveolar epithelial cells. Accumulation of inactive cyclin E-CDK2 complexes. J. Biol. Chem. 271, 25117-25125.

Cosgrove, J.P., Borish, E.T., Church, D.F., Pryor, W.A., 1985. The metalmediated formation of hydroxyl radical by aqueous extracts of cigarette tar. Biochem. Biophys. Res. Commun. 132, 390-396.

Dalle-Donne, I., Rossi, R., Milzani, A., Di Simplicio, P., Colombo, R., 2002. The actin cytoskeleton response to oxidants: from small heat shock protein phosphorylation to changes in the redox state of actin itself. Free Radic. Biol. Med. 31, 1624-1632.

Davies, K.J., 1995. Oxidative stress: the paradox of aerobic life. Biochem. Soc. Symp. 61, 1-31.

Davies, K.J., 2000. Oxidative stress, antioxidant defenses, and damage removal, repair and replacement systems. IUBMB Life 50, 279-289.

DeGregori, J., Kowalik, T., Vevins, J.R., 1995. Cellular targets for activation by the E2F transcription factor include DNA synthesis- and $\mathrm{G}_{1} / \mathrm{S}$ regulatory genes. Mol. Cell. Biol. 15, 4215-4224.

Demple, B., Harrison, L., 1994. Repair of oxidative damage to DNA enzymology and biology. Annu. Rev. Biochem. 63, 915-948.

Dérijard, B., Hibi, M., Wu, I.-H., Barrett, T., Su, B., Deng, T., Karin, M., Davis, R.J., 1994. JNK1: a protein kinase stimulated by UV light and Ha-Ras that binds and phosphorylates the c-Jun activation domain. Cell 76, $1025-1037$.

Devary, Y., Gottlieb, R.A., Lau, L., Karin, M., 1991. Rapid and preferential activation of the c-jun gene during the mammalian UV response. Mol. Cell. Biol. 11, 2804-2811.

de Wit, R., Boonstra, J., Verkleij, A.J., Post, J.A., 1998. Large scale screening for the phosphorylation of MAPKinase in cells. J. Biomol. Screen. 3, 277-284

de Wit, R., Makkinje, M., Boonstra, J., Verkleij, A.J., Post, J.A., 2001 Hydrogen peroxide reversibly inhibits Epidermal Growth Factor (EGF) receptor internalization and coincident ubiquitination of the EGF receptor and Eps15. FASEB J. 15, 306-308.

Diakonova, M., Payrastre, B., van Velzen, A.G.., Hage, W.J., van Bergen en Henegouwen, P.M.P., Boonstra, J., Cremers, A.F.M., Humbel, B.M., 1995. Epidermal growth factor induces rapid and transient association of phospholipase C-gamma 1 with EGF-receptor and filamentous actin at membrane ruffles of A431 cells. J. Cell. Sci. 108, 2499-2509.

Eferl, R., Wagner, E.F., 2003. AP-1: a double-edged sword in tumorigenesis. Nat. Rev., Cancer 3, 859-868.

Ekholm, S.V., Reed, S.I., 2000. Regulation of G(1) cyclin-dependent kinases in the mammalian cell cycle. Curr. Opin. Cell Biol. 12, 676-684.

Esposito, F., Cuccovillo, F., Russo, L., Casella, F., Russo, T., Cimino, F., 1998. A new $\mathrm{p} 21^{\text {waf } 1 / \text { cip } 1}$ isoform is an early event of cell response to oxidative stress. Cell Death Differ. 5, 940-945.

Esumi, H., Chin, K., Kurashima, Y., Hasegawa, F., Ogura, T., Yoneda, M., Ozawa, T., 1997. Reversible cell cycle arrest with concomitant p21/ WAF1 overexpression and mitochondrial destruction by nitric oxide. Biochem. Mol. Biol. Int. 42, 779-787.

Finkel, T., Holbrook, N.J., 2000. Oxidants, oxidative stress and the biology of ageing. Nature 408, 239-247.

Fotedar, R., Fotedar, A., 1995. Cell cycle control of DNA replication. Prog. Cell Cycle Res. 1, 73-89.

Fratelli, M., Demol, H., Puype, M., Casagrande, S., Villa, P., Eberini, I., Vandekerckhove, J., Gianazza, E., Ghezzi, P., 2003. Identification of proteins undergoing glutathionylation in oxidatively stressed hepatocytes and hepatoma cells. Proteomics 3, 1154-1161.

Gamou, S., Shimizu, N., 1995. Hydrogen peroxide preferentially enhances the tyrosine phosphorylation of epidermal growth factor receptor. FEBS Lett. 357, 161-164.

Gansauge, S., Nussler, A.K., Beger, H.G., Gansauge, F., 1998. Nitric ox- ide-induced apoptosis in human pancreatic carcinoma cell lines is associated with a $\mathrm{G}_{1}$-arrest and an increase of the cyclin-dependent kinase inhibitor $\mathrm{p} 21^{\mathrm{WAF} 1 / \mathrm{CIP} !}$. Cell Growth Differ. 9, 611-617.

Gartel, A.L., Tyner, A.L., 1999. Transcriptional regulation of the p21(WAF1/CIP1) gene. Exp. Cell Res. 246, 280-289.

Giulivi, C., Davies, K.J., 1993. Dityrosine and tyrosine oxidation products are endogenous markers for the selective proteolysis of oxidatively modified red blood cell hemoglobin by (the 19S) proteasome. J. Biol. Chem. 268, 8752-8759.

Gold, L.S., Slone, T.H., Stern, B.R., Manley, N.B., Ames, B.N., 1992. Rodent carcinogens: setting priorities. Science 258, 261-265.

González-Rubio, M., Voit, S., Rodríguez-Puyol, D., Weber, M., Marx, M., 1996. Oxidative stress induces tyrosine phophorylation of PDGF $\alpha$ - and $\beta$-receptors and pp60 $0^{\mathrm{c}-\mathrm{src}}$ in mesangial cells. Kidney Int. 50, 164-173.

Gopalakrishna, R., Jaken, S., 2000. Protein kinase C signaling and oxidative stress. Free Radic. Biol. Med. 28, 1349-1361.

Groß, S., Knebel, A., Tenev, T., Neininger, A., Gaestel, M., Herrlich, P., Böhmer, F.D., 1999. Inactivation of protein-tyrosine phosphatases as mechanism of UV-induced signal transduction. J. Biol. Chem. 274, $26378-26386$

Grune, T., Davies, K.J., 1997. Breakdown of oxidized proteins as a part of secondary antioxidant defenses in mammalian cells. BioFactors 6 , $165-172$.

Gutkind, J.S., 1998. Cell growth control by G protein-coupled receptors: from signal transduction to signal integration. Oncogene 17, 1331-1342.

Guyton, K.Z., Liu, Y., Gorospe, M., Xu, Q., Holbrook, N.J., 1996. Activation of Mitogen-activated protein kinase by $\mathrm{H}_{2} \mathrm{O}_{2}$. Role in cell survival following oxidant injury. J. Biol. Chem. 271, 4138-4142.

Halliwell, B., Gutteridge, J.M.C., 1990. Role of free radicals and catalytic metal ions in human disease: an overview. Methods Enzymol. 186, $1-85$.

Halliwell, B., Gutteridge, J.M.C., 1999. Free Radicals in Biology and Medicine, Third edition. Oxford Univ. Press, Oxford.

Hardwick, J.S., Sefton, B.M., 1997. The activated form of the Lck tyrosine protein kinase in cells exposed to hydrogen peroxide is phosphorylated at both Tyr-394 and Tyr-505. J. Biol. Chem. 272, 25429-25432.

Heldin, C.-H., 1996. Protein tyrosine kinase receptors. Cancer Surv. 27, $7-24$.

Helt, C.E., Rancourt, R.C., Staversky, R.J., O’Reilly, M.A., 2001. p53dependent induction of p21 (Cip1/WAF1/Sdi1) protects against oxygen-induced toxicity. Toxicol. Sci. 63, 214-222.

Holbrook, N.J., Ikeyama, S., 2002. Age-related decline in cellular response to oxidative stress: links to growth factor signaling pathways with common defects. Biochem. Pharmacol. 64, 999-1005.

Honore, S., Kovacic, H., Pichard, V., Briand, C., Rognoni, J.B., 2003. Alpha2beta1-integrin signaling by itself controls G1/S transition in a human adenocarcinoma cell line (Caco-2): implication of $\mathrm{NADPH}$ oxidase-dependent production of ROS. Exp. Cell Res. $285,59-71$

Hulleman, E., Boonstra, J., 2001. Regulation of G1 phase progression by growth factors and the extracellular matrix. Cell. Mol. Life Sci. 58, $80-93$.

Hulleman, E., van Rossum, G.S.A.T., 2003. Regulation of G1 phase progression by growth factors. In: Boonstra, J. (Ed.), G1 Phase Progression. Kluwer Academic/Plenum, New York, pp. 93-109. ISBN: 0-30647831-5.

Hulleman, E., Bijvelt, J.J.M., Verkleij, A.J., Verrips, C.T., Boonstra, J., 1999. Nuclear translocation of mitogen-activated protein kinase $\mathrm{p} 42^{\mathrm{MAPK}}$ during the ongoing cell cycle. J. Cell. Physiol. 180, 325-333.

Huot, J., Houle, F., Marceau, F., Landry, J., 1997. Oxidative stress-induced actin reorganization mediated by the $\mathrm{p} 38$ mitogen-activated protein kinase/heat shock protein 27 pathway in vascular endothelial cells. Circ. Res. 80, 383-392.

Irani, K., Goldschmidt-Clermont, P.J., 1998. Ras, superoxide and signal transduction. Biochem. Pharmacol. 55, 1339-1346.

Irani, K., Xia, Y., Zweier, J.L., Sollott, S.J., Der, C.J., Fearon, E.R., Sundaresan, M., Finkel, T., Goldschmidt-Clermont, P.J., 1997. Mitogenic 
signaling mediated by oxidants in ras-transformed fibroblasts. Science $275,1649-1652$.

Ishida, A., Sasaguri, T., Kosaka, C., Nojima, H., Ogata, J., 1997. Induction of the cyclin-dependent kinase inhibitor $\mathrm{p} 21^{\text {Sdi1/Cip1/Wafl }}$ by nitric oxide-generating vasodilator in vascular smooth muscle cells. J. Biol. Chem. 272, 10050-10057.

Iwai, K., Drake, S.K., Wehr, N.B., Weissman, A.M., LaVaute, T., Minato, N., Klausner, R.D., Levine, R.L., Rouault, T.A., 1998. Iron-dependent oxidation, ubiquitination, and degradation of iron regulatory protein 2 : implications for degradation of oxidized proteins. Proc. Natl. Acad. Sci. U. S. A. $95,4924-4928$.

Jahngen-Hodge, J., Obin, M.S., Gong, X., Shang, F., Nowell Jr., T.R., Gong, J., Abasi, H., Blumberg, J., Taylor, A., 1997. Regulation of ubiquitin-conjugating enzymes by glutathione following oxidative stress. J. Biol. Chem. 272, 28218-28226.

Juliano, R.L., 2003. Regulation of signaling and the cell cycle by cell interactions with the extracellular matrix. In: Boonstra, J. (Ed.), G1 Phase Progression. Kluwer Academic/Plenum, New York, pp. 110119. ISBN: 0-306-47831-5.

Kanno, S., Iwai, S., Takao, M., Yasui, A., 1999. Repair of apurinic/apyrimidinic sites by UV damage endonuclease; a repair protein for UV and oxidative damage. Nucleic Acids Res. 27, 3096-3103.

Kasid, U., Suy, S., Dent, P., Ray, S., Whiteside, T.L., Sturgill, T.W., 1996. Activation of Raf by ionizing radiation. Nature 382, 813-816.

Kim, Y.K., Han, J.W., Woo, Y.N., Chun, J.K., Yoo, J.Y., Cho, E.J., Hong, S., Lee, H., Lee, Y.W., Lee, H.W., 2003. Expression of p21(WAF1/ Cip1) through Sp1 sites by histone deacetylase inhibitor apicidin requires PI 3-kinase-PKC epsilon signaling pathway. Oncogene 22, $6023-6031$.

King, R.W., Deshaies, R.J., Peters, J.M., Kirschner, M.W., 1996. How proteolysis drives the cell cycle. Science 274, 1652-1659.

Knebel, A., Rahmsdorf, H.J., Ullrich, A., Herrlich, P., 1996. Dephosphorylation of receptor tyrosine kinases as targets of regulation by radiation, oxidants or alkylating agents. EMBO J. 15, 5314-5325.

Koepp, D.M., Harper, J.W., Elledge, S.J., 1999. How the cyclins became a cyclin: regulated proteolysis in the cell cycle. Cell 97, 431-434.

LaBaer, J., Garrett, M.D., Stevenson, L.F., 1997. New functional activities for the p21 family of CDK inhibitors. Genes Dev. 11, 847-862.

Lander, H.M., Jacovina, A.T., Davis, R., Tauras, J.M., 1996. Differential activation of mitogen-activated protein kinases by nitric oxide-related species. J. Biol. Chem. 271, 19705-19709.

Lauffer, R.B., 1992. Iron and Human Disease. CRC Press, Boca Raton, FL.

Lavrovsky, Y., Chatterjee, B., Clark, R.A., Roy, A.K., 2000. Role of redoxregulated transcription factors in inflammation, aging and age-related diseases. Exp. Gerontol. 35, 521-532.

Lee, S., Helfman, D.M., 2004. Cytoplasmic p $21^{\mathrm{Cip} 1}$ is involved in rasinduced inhibition of the ROCK/LIMK/Cofilin pathway. J. Biol. Chem. 279, $1885-1891$.

Lee, S.-R., Kwon, K.-S., Kim, S.-R., Rhee, S.G., 1998. Reversible inactivation of protein-tyrosine phosphatase 1B in A431 cells stimulated with epidermal growth factor. J. Biol. Chem. 273, 15366-15372.

Leonarduzzi, G., Arkan, M.C., Basaga, H., Chiarpotto, E., Sevanian, A., Poli, G., 2000. Lipid oxidation products in cell signaling. Free Radic. Biol. Med. 28, 1370-1378.

Levine, A., 1997. P53 the cellular gatekeeper for growth and division. Cell $88,323-331$.

Levine, R.L., 2002. Carbonyl modified proteins in cellular regulation, aging, and disease. Free Radic. Biol. Med. 32, 790-796.

Li, Y.P., Chen, Y., Li, A.S., Reid, M.B., 2003. Hydrogen peroxide stimulates ubiquitin-conjugating activity and expression of genes for specific E2 and E3 proteins in skeletal muscle myotubes. Am. J. Physiol., Cell Physiol. 285, C806-C812.

Macip, S., Igarashi, M., Fang, L., Chen, A., Pan, Z.-Q., Lee, S.W., Aaronson, S.A., 2002. Inhibition of p21-mediated ROS accumulation can rescue p21-induced senescence. EMBO J. 21, 2180-2188.

Mackaness, G.B., 1970. The monocyte in cellular immunity. Semin. Hematol. $7,172-184$
Martindale, J.L, Holbrook, N.J., 2002. Cellular response to oxidative stress: signaling for suicide and survival. J. Cell. Physiol. 192, 1-15.

Martínez Muñoz, C., Post, J.A., Verkleij, A.J., Verrips, C.T., Boonstra, J., 2001. The effect of hydrogen peroxide on the cyclin D expression in fibroblasts. Cell. Mol. Life Sci. 58, 990-996.

Martínez Muñoz, C., van Meeteren, L.A., Post, J.A., Verkleij, A.J., Verrips, C.T., Boonstra, J., 2002. Hydrogen peroxide inhibits cell cycle progression by inhibition of the spreading of mitotic $\mathrm{CHO}$ cells. Free Radic. Biol. Med. 33, 1061-1072.

McGrath, S.A., 1998. Induction of $\mathrm{p} 21^{\mathrm{WAF} / \mathrm{CIP} 1}$ during hyperoxia. Am. J. Respir. Cell Mol. Biol. 18, 179-187.

Meier, B., Radeke, H.H., Selle, S., Younes, M., Sies, H., Resch, K., Habermehl, G.G., 1989. Human fibroblasts release reactive oxygen species in response to interleukin-1 or tumor necrosis factor- $\alpha$. Biochem. J. 263, $539-545$.

Meucci, E., Mordente, A., Martorana, G.E., 1991. Metal-catalyzed oxidation of human serum albumin: conformational and functional changes. Implications in protein aging. J. Biol. Chem. 266, 4692-4699.

Meyer, M.R., Schreck, R., Baeuerle, P.A., 1993. $\mathrm{H}_{2} \mathrm{O}_{2}$ and antioxidants have opposite effects on activation of NF-kappa B and AP-1 in intact cells: AP-1 as secondary antioxidant-responsive factor. EMBO J. 12, 2005-2015.

Moldovan, L., Irani, K., Moldovan, N.I., Finkel, T., Goldschmidt-Clermont, P.J., 1999. The actin cytoskeleton reorganization induced by Rac1 requires the production of superoxide. Antioxid. Redox Signal. $1,29-43$.

Murray, A., 1995. Cyclin ubiquitination: the destructive end of mitosis. Cell 81, 149-152.

Nigg, E.A., 1995. Cyclin-dependent protein kinases: key regulators of the eukaryotic cell cycle. BioEssays 17, 472-480.

Norbury, C., Nurse, P., 1992. Animal cell cycle and their control. Ann. Rev. Biochem. 61, 441-470.

Obaya, A.J., Sedivy, J.M., 2002. Regulation of cyclin-Cdk activity in mammalian cells. Cell. Mol. Life Sci. 59, 126-142.

Obin, M., Shang, F., Gong, X., Handelman, G., Blumberg, J., Taylor, A., 1998. Redox regulation of ubiquitin-conjugating enzymes: mechanistic insights using the thiol-specific oxidant diamide. FASEB J. 12, 561-569.

Ohba, M., Shibanuma, M., Kuroki, T., Nose, K., 1994. Production of hydrogen peroxide by transforming growth factor- $\beta 1$ and its involvement in induction of egr-1 in mouse osteoblastic cells. J. Cell Biol. 126, 1079-1088.

Ohtsubo, M., Theodoras, A.M., Schumacher, J., Roberts, J.M., Pagano, M., 1995. Human cyclin $E$, a nuclear protein essential for the $\mathrm{G}_{1}$-to-S phase transition. Mol. Cell. Biol. 15, 2612-2624.

Peus, D., Vasa, R.A., Beyerle, A., Meves, A., Krautmacher, C., Pittelkow, M.R., 1999a. UVB activates Erk1/2 and p38 signaling pathways via reactive oxygen species in cultured keratinocytes. J. Invest. Dermatol. $112,751-756$.

Peus, D., Meves, A., Vasa, R.A., Beyerle, A., O'Brien, T., Pittelkow, M.R., 1999b. $\mathrm{H}_{2} \mathrm{O}_{2}$ is required for UVB-induced EGF receptor and downstream signaling pathway activation. Free Radic. Biol. Med. 27, 1197-1202.

Pines, J., 1995. Cyclins and cyclin-dependent kinases: theme and variations. Adv. Cancer Res. 66, 181-212.

Pollycove, M., Feinendegen, L.E., 2003. Radiation-induced versus endogenous DNA damage: possible effect of inducible protective responses in mitigating endogenous damage. Human Exp. Toxicol. 22, 290-306.

Rancourt, R.C., Staversky, R.J., Keng, P.C., O’Reilly, M.A., 1999. Hyperoxia inhibits proliferation of $\mathrm{Mv} 1 \mathrm{Lu}$ epithelial cells independent of TGF- $\beta$ signaling. Am. J. Physiol. 277, L1172-L1178.

Rancourt, R.C., Keng, P.C., Helt, C.E., O'Reilly, M.A., 2001. The role of p21 Cip1/WAF1 in growth of epithelial cells exposed to hyperoxia. Am. J. Physiol. 280, L617-L626.

Rancourt, R.C., Hayes, D.D., Chess, P.R., Keng, P.C., O'Reilly, M.A., 2002. Growth arrest in G1 protects against oxygen-induced DNA damage and cell death. J. Cell. Physiol. 193, 26-36.

Rao, G.N., 1996. Hydrogen peroxide induces complex formation of SHCGrb2-SOS with receptor tyrosine kinase and activates Ras and extrac- 
elullar signal-regulated protein kinases group of mitogen-activated protein kinases. Oncogene 13, 713-719.

Rao, G.N., 1997. Protein tyrosine kinase activity is required for oxidantinduced extracellular signal-regulated protein kinase activation and cfos and c-jun expression. Cell. Signal. 9, 181-187.

Rashba-Step, J., Tatoyan, A., Duncan, R., Ann, D., Pushpa-Rehka, T.R., Sevanian, A., 1997. Phospholipid peroxidation induces cytosolic phospholipase A2 activity: membrane effects versus enzyme phosphorylation. Arch. Biochem. Biophys. 343, 44-54.

Reed, S.I., 1997. Control of the $\mathrm{G}_{1} / \mathrm{S}$ transition. Cancer Surv. 29, 7-23.

Reed, S.I., Bailly, E., Dulic, V., Hengst, L., Resnetzky, D., Slingerland, J., 1994. $\mathrm{G}_{1}$ control in mammalian cells. J. Cell Sci., Suppl. 18, 69-73.

Reinheckel, T., Sitte, N., Ullrich, O., Kuckelkorn, U., Davies, K.J., Grune, T., 1998. Comparative resistance of the 20S and 26S proteasome to oxidative stress. Biochem. J. 335, 637-642.

Rice-Evans, C., Burdon, R., 1993. Free radical-lipid interactions and their pathological consequences. Prog. Lipid Res. 32, 71-110.

Roussel, M.F., 1998. Key effectors of signal transduction and $\mathrm{G}_{1}$ progression. Adv. Cancer Res. 69, 1-24.

Rueckert, R.R., Mueller, G.C., 1960. Effect of oxygen tension on HeLa cell growth. Cancer Res. 20, 944-949.

Russo, T., Zambrano, N., Esposito, F., Ammendola, R., Cimino, F., Fiscella, M., Jackman, J., O'Connor, P.M., Anderson, C.W., Appella, E., 1995. A p53-independent pathway for activation of WAF1/CIP1 expression following oxidative stress. J. Biol. Chem. 270, 29386-29391.

Schafer, K.A., 1998. The cell cycle: a review. Vet. Pathol. 35, 461-478.

Schieven, G.L., Kirihara, J.M., Myers, D.E., Ledbetter, J.A., Uckun, F.M., 1993. Reactive oxygen intermediates activate NF-kappa B in a tyrosine kinase-dependent mechanism and in combination with vanadate activate the p561ck and p59fyn tyrosine kinases in human lymphocytes. Blood 82, 1212-1220.

Schmidt, K.N., Amstad, P., Cerutti, P., Baeuerle, P.A., 1996. Identification of hydrogen peroxide as the relevant messenger in the activation pathway of transcription factor NF-kappaB. Adv. Exp. Med. Biol. 387, 63-68.

Schreck, R., Rieber, R., Baeuerle, P.A., 1991. Reactive oxygen intermediates as apparently widely used messengers in the activation of the NFkB transcription factor and HIV-1. EMBO J. 10, 2247-2258.

Shackelford, R.E., Kaufmann, W.K., Paules, R.S., 2000. Oxidative stress and cell cycle checkpoint function. Free Radic. Biol. Med. 28, $1387-1404$

Shang, F., Taylor, A., 1995. Oxidative stress and recovery from oxidative stress are associated with altered ubiquitin conjugating and proteolytic activities in bovine lens epithelial cells. Biochem. J. 307, 297-303.

Shenberger, J.S., Dixon, P.S., 1999. Oxygen induces S-phase growth arrest and increases $\mathrm{p} 53$ and $\mathrm{p} 21$ (WAF1/Cip1) expression in human bronchial smooth-muscle cells. Am. J. Respir. Cell Mol. Biol. 21, 395-402.

Sherr, C.J., 1995. D-type cyclins. Trends Biochem. Sci. 20, 187-190.

Sherr, C.J., Roberts, J.M., 1999. CDK inhibitors: positive and negative regulators of G1 phase progression. Genes Dev. 13, 1501-1512.

Squier, T.C., 2001. Oxidative stress and protein aggregation during biological aging. Exp. Gerontol. 36, 1539-1550.

Stadtman, E.R., 1998. The role of free radical mediation of protein oxidation in aging and disease. In: Özben, T. (Ed.), Free Radicals, Oxidative Stress, and Antioxidants. Pathological and Physiological Significance, vol. 296. Plenum Press, New York.

Stadtman, E.R., 2001. Protein oxidation in aging and age-related diseases. Ann. N.Y. Acad. Sci. 928, 22-38.

Stadtman, E.R., Levine, R.L., 2003. Free radical-mediated oxidation of free amino acids and amino acid residues in proteins. Amino Acids 25, 207-218.

Stevenson, M.A., Pollock, S.S., Coleman, C.N., Calderwood, S.K., 1994. $\mathrm{X}$-irradiation, phorbol esters, and $\mathrm{H}_{2} \mathrm{O}_{2}$ stimulate mitogen-activated protein kinase activity in NIH-3T3 cells through the formation of reactive oxygen intermediates. Cancer Res. 54, 12-15.

Stone, K., Pryor, W.A., 1994. Cigarettes: then and now. J. Lab. Clin. Med. 124, 313-314.

Sullivan, S.G., Chiu, D.T.-Y., Errasfa, M., Wang, J.M., Qi, J.-S., Stern, A., 1994. Effects of $\mathrm{H}_{2} \mathrm{O}_{2}$ on protein tyrosine phophatase activity in HER14 cells. Free Radic. Biol. Med. 16, 399-403.

Sundaresan, M., Yu, Z.X., Ferrans, V.J., Irani, K., Finkel, T., 1995. Requirement for generation of $\mathrm{H}_{2} \mathrm{O}_{2}$ for platelet-derived growth factor signal transduction. Science 270, 296-299.

Szweda, P.A., Friguet, N., Szweda, L.I., 2002. Proteolysis, free radicals, and aging. Free Radic. Biol. Med. 33, 29-36.

Thorn, T., Gniadecki, R., Petersen, A.B., Vicanova, J., Wulf, H.C., 2001. Differences in activation of $\mathrm{G} 2 / \mathrm{M}$ checkpoint in keratinocytes after genotoxic stress induced by hydrogen peroxide and ultraviolet radiation. Free Radic. Res. 35, 405-416.

Turpaev, K.T., 2002. Reactive oxygen species and regulation of gene expression. Biochemistry (Moscow) 67, 281-292.

Tyner, A.L., Gartel, A.L., 2003. Roles of cyclin kinase inhibitors in G1 phase progression. In: Boonstra, J. (Ed.), G1 Phase Progression. Kluwer Academic/Plenum, New York, pp. 58-76. ISBN: 0-306-47831-5.

van den Berg, J.J., Op den Kamp, J.A., Lubin, B.H., Kuypers, F.A., 1993. Conformational changes in oxidized phospholipids and their preferential hydrolysis by phospholipase A2: a monolayer study. Biochemistry 32, 4962-4967.

van der Vlies, D., Woudenberg, J., Post, J.A., 2003. Protein oxidation in aging: endoplasmic reticulum as a target. Amino Acids 25, 397-407.

van Rossum, G.S.A.T., Drummen, G.P.C., Verkleij, A.J., Post, J.A., Boonstra, J., 2004. Activation of cytosolic phospholipase A2 in Her14 fibroblasts by hydrogen peroxide: a $42 / 44^{\mathrm{MAPK}}$ dependent and a phosphorylation independent mechanism. Biochim. Biophys. Acta 1636, $183-195$

Vidal, A., Koff, A., 2000. Cell cycle inhibitors: three families united by a common cause. Gene 247, 1-15.

Wang, X., McCullough, K.D., Franke, T.F, Holbrook, N.J., 2000. Epidermal growth factor receptor-dependent Akt activation by oxidative stress enhances cell survival. J. Biol. Chem. 275, 14624-14631.

Wang, J., Boja, E.S., Tan, W., Tekle, E., Fales, H.M., English, S., Mieyal, J.J., Chock, P.B., 2001. Reversible glutathionylation regulates actin polymerization in A431 cells. J. Biol. Chem. 276, 47763-47766.

Wilson III, D.M., Sofinowski, T.M., McNeill, D.R., 2003. Repair mechanisms for oxidative DNA damage. Front. Biosci. 8, 963-981.

Yee, A.S., Wang, J.Y.J., 2003. Role of RB/E2F in G1 phase progression. In: Boonstra, J. (Ed.), G1 Phase Progression. Kluwer Academic/Plenum, New York, pp. 77-109. ISBN: 0-306-47831-5.

Zhang, P., Wang, Y.-Z., Kagan, E., Bonner, J.C., 2000. Peroxynitrite targets the epidermal growth factor receptor, raf-1 and MEK independently to activate MAPK. J. Biol. Chem. 275, 22479-22486.

Zhang, Z., Huang, C., Li, J., Leonard, S.S., Lanciotti, R., Butterworth, L., Shi, X., 2001. Vanadate-induced cell growth regulation and the role of reactive oxygen species. Arch. Biochem. Biophys. 392, 311-320.

Zhang, Z., Leonard, S.S., Huang, C., Vallyathan, V., Castranova, V., Shi, X., 2003. Role of reactive oxygen species and MAPKs in vanadateinduced $\mathrm{G}_{2} / \mathrm{M}$ phase arrest. Free Radic. Biol. Med. 34, 1333-1342. 